\title{
Sistem Informasi Human Resource Pada PT Sinar Raflesia Selatan Berbasis Web
}

\author{
Utami Indriyani ${ }^{1)}$, Mira Ziveria ${ }^{2)}$ \\ Sistem Informasi, Institut Teknologi dan Bisnis Kalbis \\ Jalan Pulomas Selatan Kav. 22, Jakarta 13210 \\ ${ }^{1)}$ Email: utamiindriyani07@yahoo.com \\ ${ }^{2) E m a i l: m i r a . z i v e r i a @ k a l b i s . a c . i d}$
}

\begin{abstract}
PT Sinar Raflesia Selatan is a chemical company that still uses conventional human resource system in handling employee data, absences, permits and leave, so HRD PT Sinar Raflesia Selatan takes a lot of time in handling problems related to the data. The condition of the current system process to date, if the PT Sinar Raflesia South HRD is less thorough and less active in dealing with the related data then the data will not be managed quickly completed within the time period owned. This study aims to design and build a web-based human resource information system that includes presentation of employee data information, employee absenteeism, employee permission and employee leave by using waterfall system development method which includes system analysis using cross functional diagram and fishbone diagram, system design by using Unified Modeling Language (UML) modeling, system development and programming using Hypertext Preprocessor (PHP) programming language and Structure Query Language (MySQL) database and system testing using black box testing. The results of this study is a system that can be used to manage employee data, attendance, permission and leave.
\end{abstract}

Keywords: cross functional diagram, human resource information system, PHP, SQL, UML, waterfall.

\begin{abstract}
Asbtrak: PT Sinar Raflesia Selatan merupakan perusahaan bahan kimia yang masih menggunakan sistem human resource secara konvensional dalam menangani data karyawan, absensi, izin dan cuti, sehingga HRD PT Sinar Raflesia Selatan memerlukan waktu yang cukup banyak dalam menangani masalah yang berhubungan dengan data-data tersebut. Kondisi proses sistem yang sedang berjalan hingga saat ini, jika HRD PT Sinar Raflesia Selatan kurang teliti dan kurang giat dalam menangani yang berhubungan dengan data-data tersebut maka data-data yang dikelola tidak akan cepat selesai dalam jangka waktu yang dimiliki. Penelitian ini bertujuan untuk merancang dan membangun sebuah sistem informasi human resource berbasis web yang meliputi penyajian informasi data karyawan, absensi karyawan, ijin karyawan dan cuti karyawan dengan menggunkan metode pengembangan sistem waterfall yang meliputi analisa sistem dengan menggunakan cross functional diagram dan fishbone diagram, perancangan sistem dengan menggunakan pemodelan Unified Modelling Language (UML), pengembangan dan pemrograman sistem menggunakan bahasa pemrograman Hypertext Preprocessor (PHP) dan basis data Structure Query Language (SQL) serta pengujian sistem menggunakan black box testing. Hasil penelitian ini adalah sebuah sistem yang dapat digunakan untuk mengelola data karyawan, absensi, izin dan cuti.
\end{abstract}

Kata kunci: cross functional diagram, human resource information system, PHP, SQL,UML, waterfall

\section{PENDAHULUAN}

Sumber Daya Manusia dalam konteks bisnis merupakan orang yang bekerja dalam suatu organisasi yang sering disebut karyawan dan merupakan aset paling berharga dalam perusahaan, tanpa manusia maka sumber daya perusahaan tidak akan dapat mengahasilkan laba atau menambah nilainya sendiri [1]. Sumber daya manusia juga merupakan salah satu fungsi yang terdapat pada setiap organisasi. Fungsi sumber daya manusia yaitu menangani proses-proses yang berhubungan dengan operasional organisasi. Fungsi sumber daya manusia ini tidak dapat berdiri sendiri karena membutuhkan data dan informasi yang dihasilkan dari semua kegiatan dalam organisasi operasional organisasi.

Perusahaan merupakan salah satu organisasi yang menjalankan kegiatan operasional di dalamnya. Kegiatan operasional tidak akan dapat berjalan tanpa adanya sumber daya manusia. Sumber daya manusia disini adalah karyawan perusahaan yang menjalankan pekerjaannya. Sumber daya manusia di dalam perusahaan merupakan aset bagi perusahaan. Oleh sebab itu, data karyawan harus dikelola dengan benar, sehingga di dalam perusahaan sangat diperukan divisi Human Resource untuk mengelolanya. 
PT. Sinar Raflesia Selatan merupakan perusahaan yang bergerak di bidang pengelolaan bahan-bahan kimia. PT. Sinar Raflesia Selatan memiliki jumlah karyawan sebanyak 43 karyawan, sehingga membuat divisi Human Resource mengalami kesulitan dalam pengolahan data karyawan. Data karyawan yang diolah berupa data diri karyawan, data absensi karyawan, data izin karyawan, data cuti karyawan, data perekrutan karyawan, data pemberhentian karyawan, data lembur karyawan, data gaji karyawan dan data tunjangan karyawan.

Dalam proses pengolahan data-data tersebut belum terbangun sistem terintegrasi untuk divisi Human Resource. Dalam proses pengolahan absensi karyawan, PT. Sinar Raflesia Selatan menggunakan mesin amano untuk melakukan absensi karyawan. Namun untuk perekapan absensi masih melakukan penginputan secara manual ke dalam file Microsoft Excel secara manual. Hal tersebut terjadi karena mesin amano hanya dapat merekam jam karyawan masuk kantor, tetapi tidak dapat terekam secara sistem.

Proses izin tidak masuk karyawan juga masih mengunakan cara manual, yaitu karyawan harus mengisi terleih dahulu kertas form pengajuan izin yang tersedia. Pengajuan izin tidak masuk tersebut akan disampaikan ke kepala bagian oleh HRD untuk dilakukan approval dan selanjutnya akan diberikan ke direktur untuk tahap akhir persetujuan pengajuan izin tidak masuk. Perekapan yang dilakukan HRD masih dalam bentuk dokumen file Microsoft Excel.

Dalam proses pengolahan cuti karyawan masih dalam bentuk dokumen file Microsoft Excel. Bagian HRD akan melakukan pendataan cuti karyawan berdasarkan berkas form cuti yang telah disetujui oleh kepala bagian dan direktur. Form cuti yang tersedia di PT. Sinar Raflesia Selatan masih berupa form kertas yang harus diisi terlebih dahulu oleh karyawan dan membutuhkan waktu selama kurang lebih satu minggu dalam proses persetujuan pengajuan cuti.

Tidak hanya proses pendataan absensi, izin dan cuti saja yang masih menggunakan microsoft word dan excel. Pendataan data diri karyawan, data perekrutan karyawan, data pemberhentian karyawan, data lembur karyawan, data gaji karyawan dan data tunjangan karyawan juga masih dalam bentuk file microsoft word dan excel, sehingga HRD PT Sinar Raflesia Selatan memerlukan waktu yang cukup banyak dalam menangani masalah yang berhubungan dengan data-data tersebut. Melihat kondisi proses sistem yang sedang berjalan hingga saat ini, jika HRD PT Sinar Raflesia Selatan kurang teliti dan kurang giat dalam menangani yang berhubungan dengan data-data tersebut maka data-data yang dikelola tidak akan cepat selesai dalam jangka waktu yang dimiliki.

\section{METODE PENELITIAN}

Sebagai perbandingannya pada penelitian yang berjudul Sistem Informasi Manajemen Sumber Daya Manusia (Studi Kasus Bumida Syariah). Penelitian ini mengkaji tentang bagaimana merancang dan membangun aplikasi sistem informasi manajemen sumber daya manusia yang mampu mengelola informasi data lowongan kerja, data pelamar, data pengangkatan pegawai tetap, data pegawai, data pensiun, data resign, data riwayat penghargaan dan hukuman pegawai, data absensi, data cuti serta data perubahan jabatan menggunakan xampp dan PHP. Pemodelan sistem ini menggunakan Unified Modelling Language (UML) dan menggunakan metode pengembangan sistem waterfall. Sistem ini dapat menjadi sarana pengolah data secara lebih cepat, tepat dan efisien, serta mempermudah dalam penyimpanan arsip atau dokumen laporan-laporan perusahaan [2].

Berdasarkan perbandingan penelitian yang kedua dengan judul Design and Implementation of Human Resource Information Systems Based on MVC a Case Study Vocational Education in Iraq. Dalam penelitian ini mengkaji tentang bagaimana merancang dan membuat Sistem Infromasi Human Resource pada Direktorat Pendidikkan Kejuruan Iraq yang fleksibel dan transparan di antara para manajer SDM dan manajemen puncak yang akan digunakan untuk mempercepat melihat dan memperbarui status karyawan sesuai dengan hierarki organisasi. Dalam pengimplementasiannya menggunakan bahasa pemrograman Javascript, sedangkan untuk database menggunakan SQL [3].

Berdasarkan analisa dari penelitian terdahulu mengenai sistem informasi sumber daya manusia diketahuibahwapenelitiantersebutmemilikikesamaan tujuan yaitu merancang dan membangun sistem informasi sumber daya manusia untuk memudahkan mendapatkan informasi dengan menggunakan teknologi berbasis web. Sistem informasi Sumber Daya Manusia (SDM) merupakan prosedur sistematik untuk pengumpulan, menyimpan, mempertahankan, menarik, memvalidasi data yang dibutuhkan oleh sebuah perusahaan untuk meningkatkan keputusan SDM [4]. Dalam membentuk sistem informasi yang komprehensif, informasi haruslah diperoleh dari berbagai sumber. 
Metode pengembangan dan teknik pemodelan sistem menjadi rujukan peneliti dalam merancang dan membangun sistem sumber daya manusia. Sehingga penelitian tersebut menjadi acuan bagi peneliti untuk merancang dan membangun sistem informasi human resource berbasis web pada PT Sinar Raflesia Selatan.

Dalam penelitian ini, peneliti menggunakan beberapa metode penelitian untuk menjelaskan mengenai tahapan-tahapan penelitian yang akan dilakukan. Metode-metode yang dilakukan peneliti diantaranya sebagai berikut:

Metode pengumpulan data merupakan cara peneliti untuk mendapatkan informasi mengenai permasalahan dan kebutuhan yang diperlukan dalam penelitian ini. Dalam mengumpulkan data, peneliti melakukan wawancara dan observasi.

Metode pengembangan sistem yang digunakan peneliti yaitu metode waterfall. Waterfall merupakan pendekatan SDLC yang menyediakan pendekatan alur hidup perangkat lunak secara sekuensial atau terurut dimulai dari analisis, desain, pengkodean, pengujian dan tahap pendukung (support) [5]. Tahaptahap pendekatan waterfall yaitu analisis kebutuhan sistem, desain sistem, implementasi, pengujian dan support and maintenance [5].

Metode pengujian sistem digunakan untuk melakukan pengujian terhadap sistem apakah fungsifungsi yang terdapat pada sistem sudah sesuai dengan apa yang telah disetujui bersama. Metode pengujian ini juga bertujuan untuk menjamin bahwa setiap modul sudah berjalan sebagaimana mestinya. Pengujian yang dilakukan peneliti adalah pengujian black box testing yaitu dengan klasifikasi pengujian alfa (alpha testing). Pada pengujian ini, pengguna akan diundang ke pusat pengembangan. Pengguna akan menggunakan aplikasi dan pengembang mencatat setiap masukkan atau tindakan yang akan dilakukan pengguna [6].

Peneliti menggambarkan kerangka berpikir yang digunakan selama penelitian ini, seperti pada Gambar 1.

Pada tahap pertama peneliti melakukan analisis sistem, dimana peneliti melakukan analisa sistem yang sedang berjalan sampai saat ini menggunakan cross functional diagram. Selanjutnya peneliti melakukan analisis permasalahan yang ada pada PT Sinar Raflesia Selatan dengan menggunakan fishbone diagram dan melakukan analisis kelemahan sistem tersebut. Selanjutnya melakukan analisis permasalahan sistem dengan cara merumuskan kesimpulan masalah dari permasalahan yang terdapat pada sistem yang sedang berjlan. Selanjutnya peneliti dapat mengetahui sistem

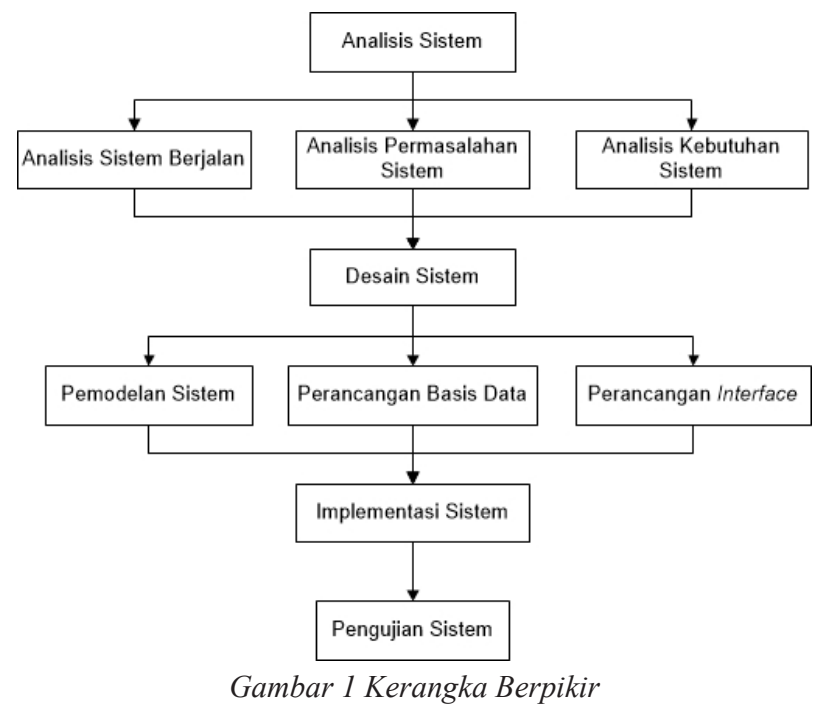

usulan yang akan dibangun dan analisa kebutuhan sistem usulan yang akan dibangun dengan kebutuhan fungsional dan non fungsional.

Tahap selanjutnya adalah peneliti akan melakukan tahap desain sistem yaitu peneliti membuat perancangan sistem dengan pemodelan sistem menggunakan cross functional diagram untuk menggambarkan proses bisnis pada proses absensi, izin dan cuti, use case diagram untuk menggambarkan aktor yang terkait dengan sistem, activity diagram untuk menjelaskan kegiatan yang dilakukan oleh setiap aktor terhadap sistem. Merancang logical model database yang menggambarkan struktur table pada perancangan database. Selanjutnya adalah perancangan interface untuk setiap halaman yang ada di dalam sistem. Perancangan tersebut merupakan desain pada setiap halaman web yang akan dibangun oleh peneliti.

Setelah desain sistem dibuat, peneliti melanjutkan ke tahap implementasi dimana peneliti melakukan pemrograman membangun aplikasi web dengan menggunakan script bahasa pemrograman Hypertext Prepocessor (PHP), Hypertext Mark Up Language (HTML) serta dalam penyimpanan data menggunakan database SQL. Setelah pemrograman selesai dilakukan maka akan menghasilkan aplikasi Sistem Informasi Human Resource PT Sinar Raflesia Selatan. Setelah program aplikasi selesai, peneliti melakukan tahap pengujiaan sistem. Pengujian ini menggunkan black box testing yaitu dengan klasifikasi alpha testing yang akan lansung dilakukan oleh pengguna terhadap sistem yang telah dibangun.

\section{HASIL DAN PEMBAHASAN}

Pada bagian ini peneliti menjelaskan analisis sistem, desain sistem impelementasi sistem dan pengujian sistem dari penelitian ini. 


\section{A. Analisis Sistem}

Analisis sistem merupakan tahap awal yang dilakukan peneliti. Langkah dalam analisis sistem terdiri dari analisis sistem berjalan, identifikasi masalah dan analisis kebutuhan sistem. Tahap tersebut dilakukan peneliti untuk merancang dan membangun sistem informasi human resource pada PT Sinar Raflesia Selatan berbasis web.

\section{Analisis Sistem Berjalan}

Pada tahap ini, peneliti melakukan analisis terhadap sistem yang sedang berjalan sampai saat ini. Peneliti melakukan observasi dan wawancara dengan Ibu Wiji Astuti sekalu HRD PT Sinar Raflesia Selatan. Wawancara ini dilakukan untuk mengetahui alur proses yang berkaitan dengan proses absensi, pengajuan cuti dan pengajuan izin karyawan yang sedang berjalan menggunakan cross functional diagram serta mengidentifikasi permasalahan yang ada menggunakan fishbone diagram.

\section{a. Cross Functional Diagram Sistem Berjalan}

Cross functional diagram sistem berjalan merupakan diagram alur yang menggambarkan proses dari kegiatan human resource yang sedang berjalan. Peneliti menggambarkan cross functional diagram sistem absensi yang sedang berjalan, sistem izin tidak masuk yang sedang berjalan, sistem cuti tahunan yang sedang berjalan, sistem cuti hamil yang sedang berjalan, sistem cuti melahirkan yang sedang berjalan dan sistem cuti gugur kandungan yang

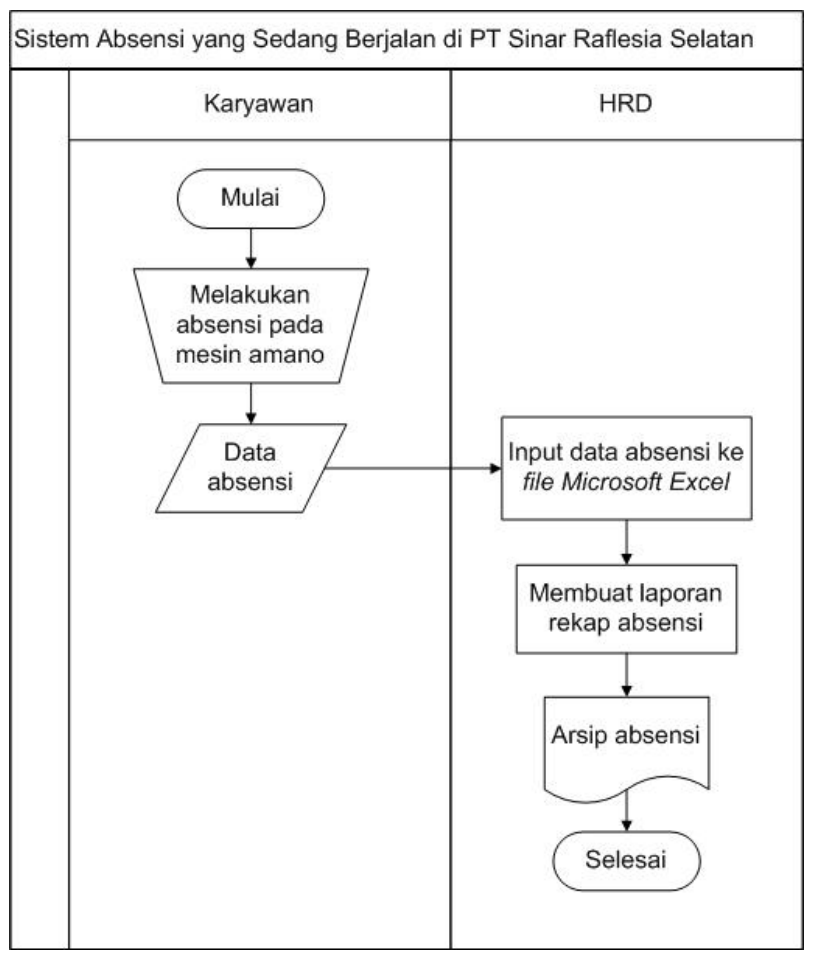

Gambar 2 Cross Functional Diagram Sistem Absensi yang Sedang Berjalan sedang berjalan. Berikut merupakan cross functional diagram sistem absensi dan sistem cuti tahunan yang sedang berjalan pada PT Sinar raflesia Selatan.

1). Cross Functional Diagram Sistem Absensi yang Sedang Berjalan

Dari Gambar 2. proses absensi karyawan yang sedang berjalan: Karyawan melakukan absensi pada mesin amano; HRD merekap absensi berdasarkan data dari mesin amano ke dalam file dokumen Microsoft Excel; dan HRD membuat laporan rekap absensi dan diarsipkan.

2). Cross Functional Diagram Sistem Cuti Tahunan yang Sedang Berjalan

Dari Gambar 3. proses cuti tahunan yang sedang berjalan: Karyawan meminta form pengajuan cuti ke bagian HRD, setelah itu melakukan pengisian form cuti; Selanjutnya karyawan menyerahkan form pengajuan cuti ke bagian HRD; Kemudian bagian HRD akan melakukan pengecekan waktu pengecekan waktu pengajuan cuti. pengajuan cuti minimal seminggu sebelum waktu cuti. Jika pengajuan cuti yang diajukan oleh karyawan kurang dari seminggu maka cuti akan ditolak dan akan memberikan informasi bahwa pengajuan cuti ditolak. Jika pengajuan cuti sudah memenuhi syarat maka HRD akan melanjutkan melakukan pengecekan jumlah cuti yang diajukan; Jumlah cuti yang diajukan dalam seminggu yaitu 2 hari. Jika jumlah cuti yang diajukan lebih dari 2 hari maka cuti akan ditolak dan akan memberikan informasi bahwa pengajuan cuti ditolak. Jika sesuai dengan ketentuan maka HRD akan melakukan pengecekan data sisa cuti karyawan; Jumlah hak cuti karyawan dalam setahun yaitu sesuai dengan masa lama bekerja di perusahaan. Jika karyawan sudah tidak memiliki sisa hak cuti maka cuti akan ditolak dan akan memberikan informasi bahwa pengajuan cuti ditolak. Jika karyawan masih memiliki sisa hak cuti maka form cuti tersebut akan diteruskan ke kepala bagian untuk dilakukan approval; Kepala bagian yang telah menerima form cuti karyawan akan melakukan pengecekan waktu cuti yang diajukan. Jika waktu yang diajukan bersamaan dengan karyawan lain dalam divisi maka kepala bagian akan memberikan informasi kepada HRD. Jika pengajuan cuti ditolak, maka HRD akan memberikan informasi kepada karyawan bahwa pengajuan cuti ditolak oleh kepala bagian. Jika waktu cuti yang diajukan tidak bersamaan dengan karyawan lain dalam 1 divisi maka pengajuan cuti diapprove oleh kepal bagian dan form pengajuan cuti akan diteruskan ke direktur untuk dilakukan approval; Direktur yang telah menerima form cuti karyawan akan melakukan approval 


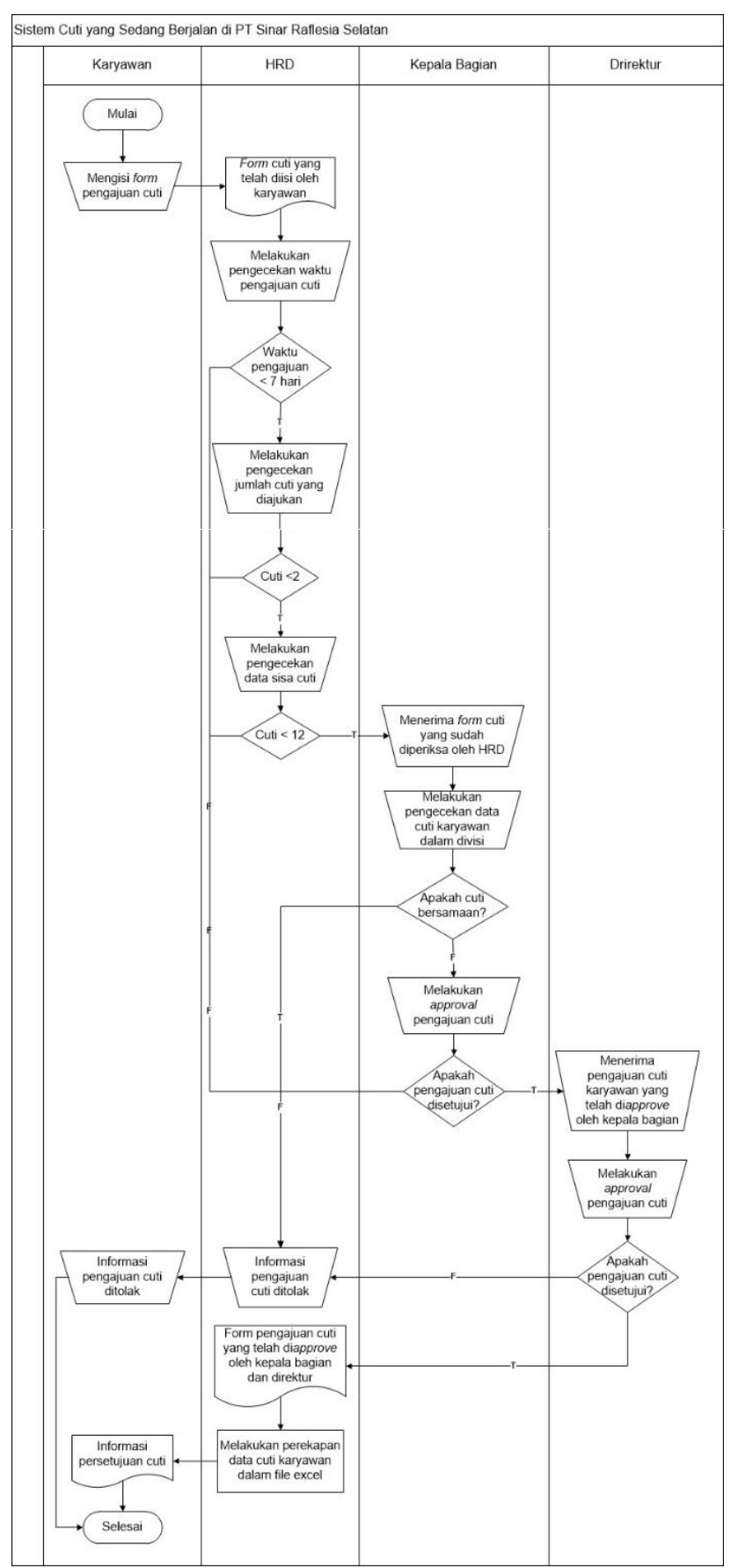

Gambar 3 Cross Functional Diagram Sistem Cuti yang Sedang Berjalan

pengajuan cuti. Jika pengajuan cuti ditolak, maka direktur akan memberikan informasi kepada HRD jika pengajuan cuti ditolak dan HRD akan memberikan informasi kepada karyawan bahwa pengajuan cuti ditolak oleh direktur. Jika pengajuan cuti diapprove oleh direktur, maka HRD akan melakukan pencatatan data cuti karyawan dan memberikan informasi kepada karyawan bahwa pengajuan cuti telah diapprove.

b. Fishone Diagram

Fishbone diagram adalah tool yang digunakan oleh perusahaan untuk mengetahui penyebabpenyebab masalah dan efek yang dihasilkan [7]. Penyebab dari masalah diidentifikasi sumber masalah secara akurat [7]. Peneliti melakukan analisis sistem yang berjalan dengan menggunakan fishbone diagram dengan penjelasan sebagai berikut: Identifikasi akibat yang dihasilkan dari proses analisis sistem yang berjalan adalah human resource PT Sinar Raflesia Selatan masih menggunakan cara konvensional yaitu pendataan masih dalam bentuk file Microsoft Word dan Excel; Pengelompokan penyebab masalah pada sistem absensi, izin dan cuti berjalan, yaitu mesin yang berkaitan dengan hardware dan software yang digunakan, metode yang terkait dengan perancangan sistem yang sedang berjalan, material yang terkait dengan informasi dalam sistem dan manusia yan terkait dengan human resource di dalam system; Faktor utama dan pendukung dari setiap penyebab antara lain mesin, manusia, material dan metode. seperti pada Gambar 4.

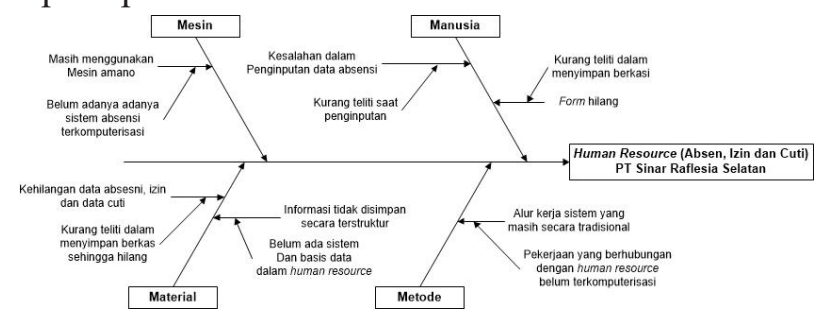

Gambar 4 Fishbone Diagram Sistem Informasi Human Resource yang Sedang Berjalan

\section{Analisis Permasalahan Sistem}

Pada fase ini, peneliti menyimpulkan terkait dengan analisis sistem yang sedang berjalan dan menghasilkan evaluasi berupa solusi sebagai berikut: Merancang dan membangun sistem informasi human resource yang dapat mengintegrasikan antara karyawan, HRD dan direktur sehingga mempermudah dalam pengolahan absensi, izin dan cuti; Perancangan sistem menggunakan metode pengembangan sistem yang sesuai dengan ruang lingkup penelitian dan waktu penelitian. Peneliti merekomendasikan metode

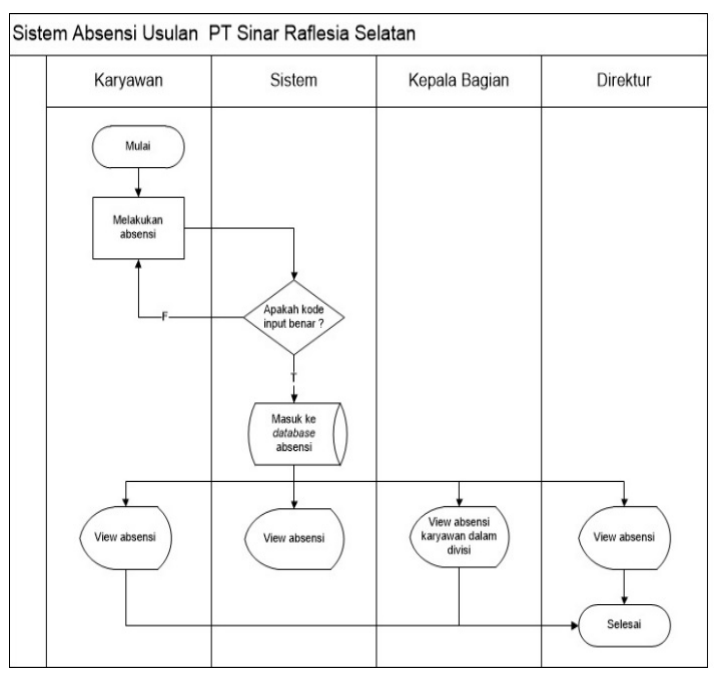

Gambar 5 Cross Functional Diagram Sistem Absensi Usulan 
pengembanan sistem waterfall; dan Kebutuhan perangkat keras dan lunak yang mendukung penggunaan aplikasi sistem berbasis web.

Berdasarkan evaluasi maka peneliti melakukan analisis sistem usulan dengan menggunakan cross functional diagram, diantaranya yaitu sistem absensi usulan, sistem izin tidak masuk usulan, sistem cuti tahunan usulan, sistem cuti hamil usulan, sistem cuti melahirkan usulan dan sistem cuti gugur kandungan usulan. Berikut merupakan cross functional diagram sistem absensi dan sistem cuti tahunan usulan yang peneliti buat pada PT Sinar Raflesia Selatan.

1). Cross Functional Diagram Sistem Absensi Usulan

Gambar 5. proses absensi karyawan usulan: Karyawan melakukan absensi clock in pada PC dengan memasukkan kode karyawan; Sistem akan memvalidasi kode tersebut. Jika sesuai maka akan tersimpan dalam database data absensi karyawan dan secara otomatis akan terekap absensinya, jika tidak sesuai maka tidak akan tersimpan dalam database data absensi karyawan kehadirannya dan karyawan harus input kembali sesuai dengan kode yang dimiliki; Admin dan direktur dapat melilihat data absensi karyawan untuk pengecekan kehadiran karyawan; Kepala bagian dapat melihat data absensi karyawan dalam divisinya; dan Karyawan dapat melihat data absensi diri.

2). Cross Functional Diagram Sistem Cuti Tahunan Usulan

Gambar 6.proses cuti tahunan karyawan usulan: Karyawan melakukan login ke dalam system; Sistem akan melakukan sinkronisasi. Jika username dan password yang dimasukkan sudah benar maka karyawan dapat melakukan pengajuan cuti. Jika username dan password yang dimasukkan salah maka karyawan harus melakukan login Kembali; Selanjutnya karyawan akan mengisi form pengajuan cuti sesuai dengan jenis cuti yang akan diajukan; Sistem akan melakukan sinkronisasi waktu pengajuan cuti. Waktu pegajuan cuti minimal seminggu sebelum cuti. Jika karyawan mengajukan cuti kurang dari seminggu dari waktu cuti maka karyawan akan mendapatkan informasi bahwa pengajuan cuti ditolak dan data penolakan pengajuan cuti akan masuk ke dalam database cuti karyawan, sedangkan jika memenuhi syarat maka sistem akan melanjutkan melakukan sinkronisasi jumlah cuti yang diajukan; Jumlah cuti maksimal 2 hari dalam seminggu. Jika cuti yang diajukan lebih dari 2 hari dalam seminggu maka karyawan akan mendapatkan informasi bahwa pengajuan cuti ditolak dan data penolakan pengajuan cuti akan masuk ke dalam database cuti karyawan,

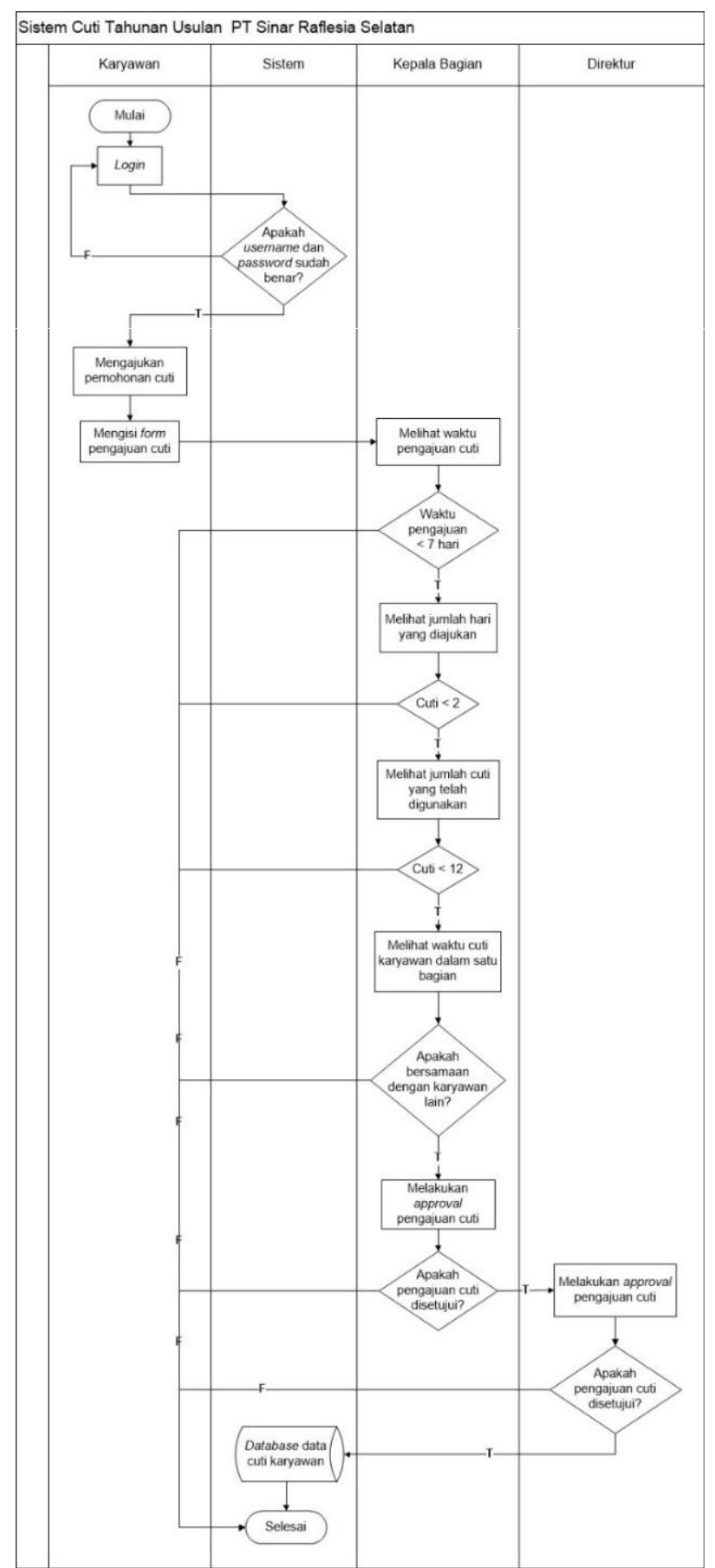

Gambar 6 Cross Functional Diagram Sistem Cuti Tahunan Usulan

sedangkan jika memenuhi syarat maka sistem akan melanjutkan melakukan sinkronisasi jumlah cuti yang masih tersisa; Jumlah cuti dalam setahun adalah 12 hari. Jika karyawan masih memiliki sisa cuti kurang dari 12 hari maka dilakukan sinkronisasi dengan jadwal cuti karyawan lain dalam satu bagian atau divisi. Jika karyawan sudah tidak memiliki sisa cuti maka karyawan akan mendapatkan informasi bahwa pengajuan cuti ditolak dan data penolakan pengajuan cuti akan masuk ke dalam database cuti karyawan; Jika waktu cuti karyawan bersamaan dengan karyawan dalam satu bagian atau divisi maka karyawan akan mendapatkan informasi bahwa 
pengajuan cuti ditolak dan data penolakan pengajuan cuti akan masuk ke dalam database cuti karyawan. Jika waktu cuti karyawan tidak bersamaan dengan karyawan lain dalam satu bagian atau divisi maka form tersebut akan dilakukan approval oleh kepala bagian; Jika kepala bagian menyetujui maka akan dilanjutkan ke direktur untuk tahap akhir persetujuan permohonan cuti. Jika tidak disetujui maka karyawan akan mendapatkan informasi bahwa pengajuan cuti ditolak dan data penolakan cuti karyawan akan masuk ke dalam database cuti karyawan; dan Form pengajuan cuti karyawan yang telah diapprove oleh kepala bagian akan diterima oleh direktur. Direktur akan melakukan approval akhir untuk persetujuan pengajuan cuti karyawan. jika disetujui oleh direktur maka karyawan akan menerima informasi bahwa pegajuan cuti tersebut disetujui dan data akan masuk ke dalamm database cuti karyawan, sedangkan jika ditolak maka karyawan akan menerima informasi bahwa pengajuan cuti ditolak dan data penolakan cuti karyawan masuk ke dalam database cuti karyawan.

\section{Analisis Kebutuhan Sistem}

Analisis kebutuhan merupakan tahapan yang menjelaskan kebutuhan sistem dalam memenuhi perancangan dan pembangunan sistem usulan. Pada tahap ini peneliti melakukan analisa terhadap kebutuhan fungsional dan non fungsional. Kebutuhan fungsional merupakan kebutuhan yang berisikan fungsi-fungsi yang dapat dilakukan oleh sistem. Kebutuhan non fungsional merupakan kebutuhan yang berkaitan dengan semua komponen dalam membangun sistem.

\section{B. Desain Sistem}

Desain sistem menjelaskan konsep sistem usulan yang terdiri dari pemodelan sistem dengan menggunakan unified model language (UML) untuk menjelaskan hal-hal yang berkaitan dengan rancangan sistem yang akan diusulkan untuk perusahaan.

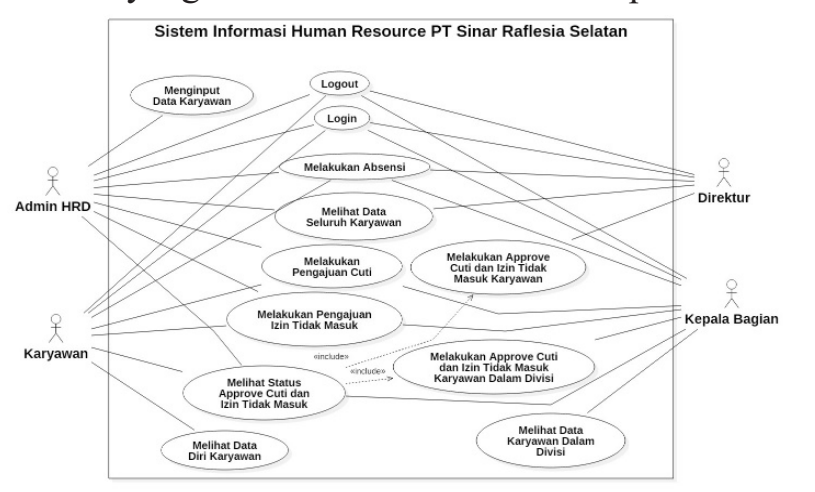

Gambar 7 Use Case Diagram Sistem Informasi Human Resource Usulan PT Sinar Raflesia Selatan
Unified Modeling Language (UML) adalah notasi yang lengkap untuk membuat visualisasi model suatu sistem. Sistem berisi informasi dan fungsi, tetapi secara normal digunakan untuk memodelkan sistem komputer. Perancangan UML ini terdiri dari use case diagram dan activity diagram. Perancangan basis data menggunakan Entity Relational Diagram (ERD), logical model database dan struktur data. Perancangan interface aplikasi yang berisi desain interface web sistem.

\section{Use Case Diagram}

Use case diagram merupakan pemodelan untuk kelakuan (behaviour) sistem informasi yang akan dibuat [8]. Use case mendeskripsikan sebuah interaksi antara satu atau lebih aktor dengan sistem informasi yang akan dibuat [8]. Use case digunakan untuk mengetahui fungsi apa saja yang ada di dalam sebuah sistem informasi dan siapa saja yang berhak menggunakan fungsi-fungsi tersebut [8]. Berikut Use case diagram sistem informasi human resource usulan pada PT Sinar Raflesia Selatan. Lihat Gambar 7.

\section{Activity Diagram}

Activity diagram menggambarkan berbagai alir aktivitas dalam sistem yang sedang dirancang, bagaimana masing-masing alir berawal, decision yang mungkin terjadi dan bagaimana mereka berakhir [9]. Activity diagram merupakan penjelasan tentang alur kerja sistem usulan berdasarkan dengan use case diagram yang telah dirancang sebelumnya dan terkait dengan sistem usulan yaitu admin, direktur, kepala bagian dan karyawan. Peneliti membuat activity diagam absensi user, login user, ubah password, mengelola data karyawan, cuti admin, izin admin, cuti karyawan, izin karyawan, cuti kepala bagian, izin kepala bagian, cuti direktur, dan izin direktur . Berikut merupakan activity untuk absensi dan cuti pada PT Sinar Raflesia Selatan.

a. Activity Diagram Absensi

User melakukan absensi dengan memasukkan username. Sistem akan memverivikasi username, jika gagal maka sistem akan meminta user memasukkan

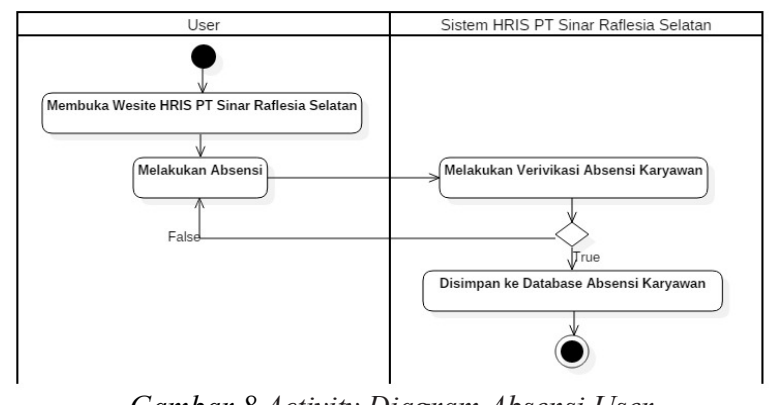

Gambar 8 Activity Diagram Absensi User 
username dan jika berhasil maka sistem akan menyimpan waktu absensi user. Lihat Gambar 8.

\section{b. Activity Diagram Cuti}

Activity diagram cuti dilakukan oleh keempat aktor yaitu admin, karyawan, kepala bagian dan direktur. Berikut activity diagram cuti yang dilakukan oleh keempat user.

\section{1). Activity Diagram Cuti Admin}

Admin dapat mengajukan cuti serta melihat status pengajuan dan data cuti karyawan. Untuk mengajukan cuti, admin hanya mengisi form yang telah ada pada aplikasi dan mensubmit pengajuan tersebut. Selain itu status pengajuan cuti juga dapat terlihat dalam aplikasi dan admin dapat melakukan pemantauan cuti yang dilakukan oleh karyawan. Pemantauan yang dilakukan admin dengan cara mencari data cuti karyawan yang ingin dilihat, sebelumnya admin harus mengetikkan nama karyawan yang akan dicari data cutinya. Setelah mengetikan nama karyawan tersebut, maka riwayat cuti karyawan akan terlihat. Seperti pada Gambar 9.

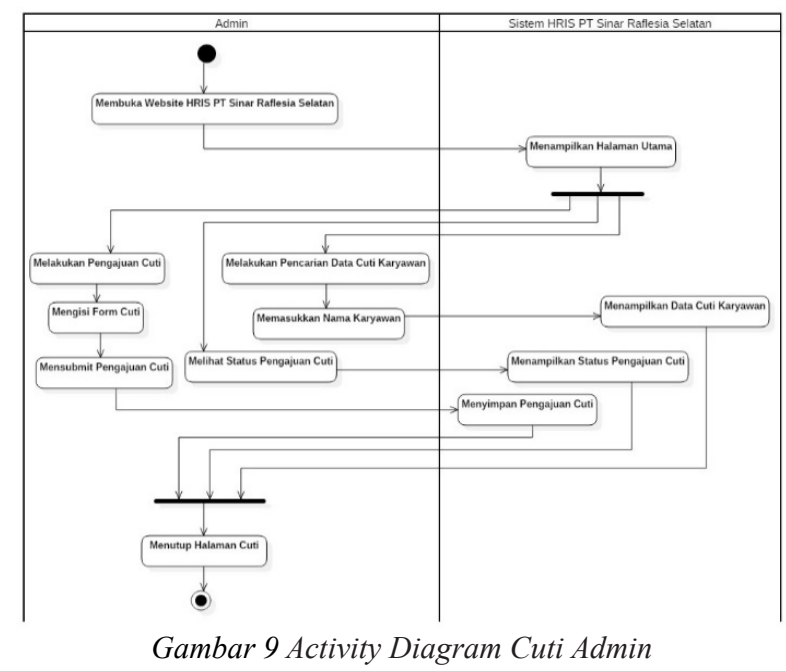

\section{2). Activity Diagram Cuti Karyawan}

Untuk melakukan pengajuan cuti, karyawan harus mengisi form pengajuan cuti terlebih dahulu, setelah mengisi form tersebut karyawan harus mensubmit pengajuan tersebut dan sistem akan menyimpan pengajuan cuti yang dilakukan oleh karyawan. Karyawan juga dapat melihat riwayat cuti yang telah dilakukan selama masa bekerja. Seperti pada Gambar 10.

\section{2). Activity Diagram Cuti Direktur}

Direktur dapat melakukan approval izin karyawan dan melihat rekap cuti karyawan. Untuk approval cuti karyawan yang dilakukan direktur, sebelumnya approval tersebut dilakukan terlebih dahulu oleh kepala bagian karena direktur melakukan approval pada tahap terakhir yaitu penentuan apakah pengajuan cuti yang diajukan oleh karyawan akan

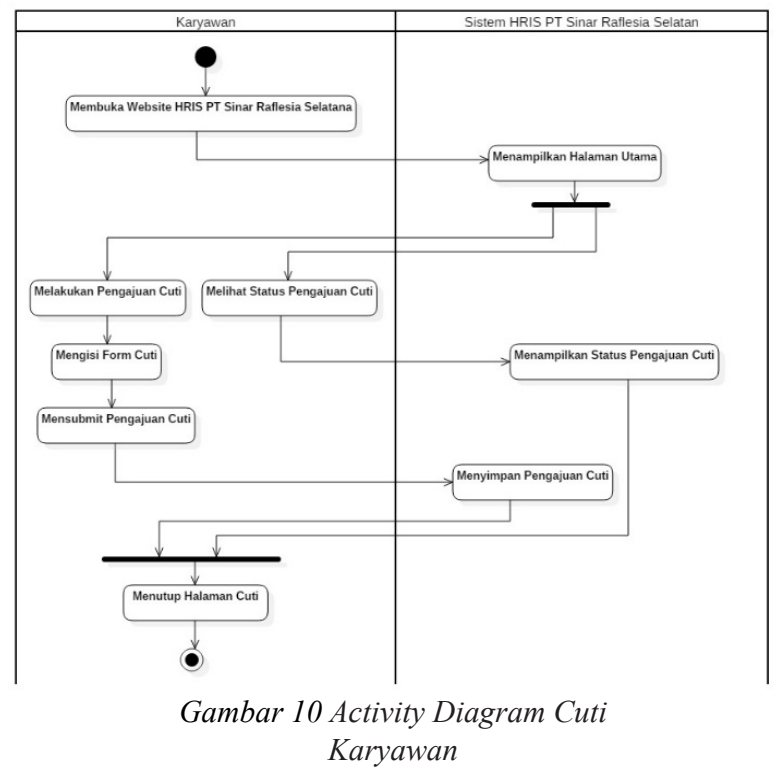

disetujui atau tidak. Dari data rekap cuti karyawan, direktur dapat pemantauan cuti yang dilakukan oleh karyawan selama masa kerjanya karena data-data tersebut. Data rekap yang dapat dilihat oleh direktur adalah data yang real time. Seperti pada Gambar 11.

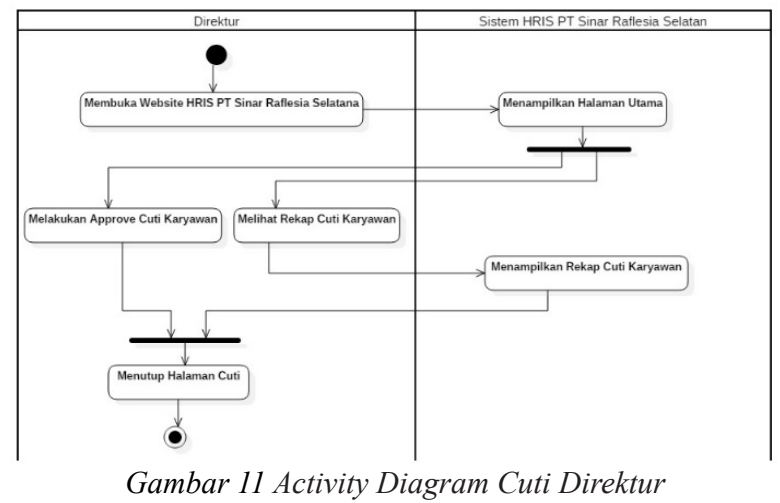

\section{3). Activity Diagram Cuti Kepala Bagian}

Kepala bagian dapat melakukan pengajuan cuti, melihat status cuti yang diajukan dan melakukan approve cuti kepala bagian. Untuk melakukan pengajuan cuti, kepala bagian harus mengisi form pengajuan cuti terlebih dahulu, setelah mengisi form tersebut kepala bagian harus mensubmit pengajuan tersebut dan sistem akan menyimpan pengajuan cuti yang dilakukan oleh kepala bagian. Kepala bagian juga dapat melihat status cuti yang diajukan oleh diri sendiri dan karyawan lain. Seperti pada Gambar 12.

\section{Perancangan Database}

Tahap selanjutnya yang dilakukan peneliti yaitu perancangan basis data yang bertujuan untuk menggambarkan hubungan antar entitas. Perancangan basis data yang dibuat oleh peneliti terdiri dari Entity Relationship Diagram (ERD), logical model database dan struktur data.

Entity Relationship Diagram (ERD) adalah pemodelan basis data berdasarkan teori himpunan 


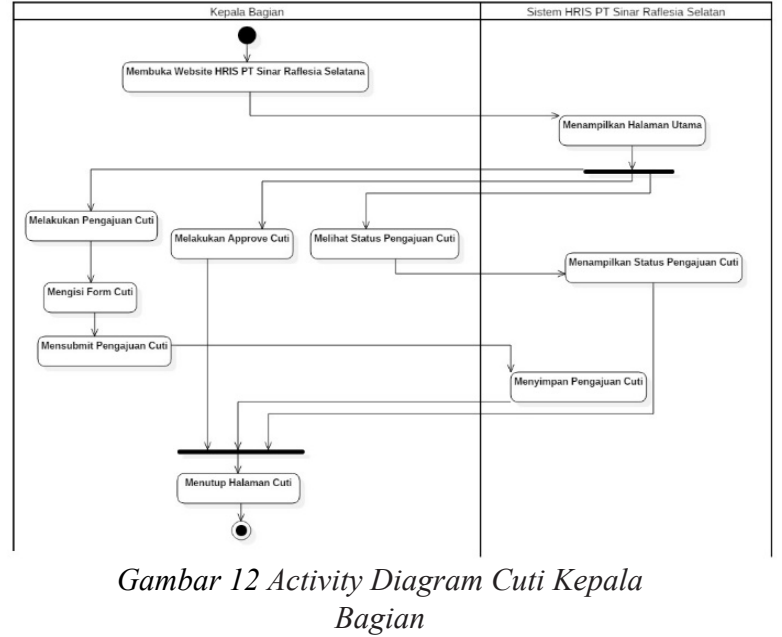

dalam bidang matematika [10]. ERD digunakan untuk pemodelan basis data relasional [10]. Logical model database merupakan penggambaran dari relasi pada ERD dalam bentuk tabel. Tabel-tabel pada database sistem human resource ini terdiri dari tabel ms_karyawan, ms_jabatan, ms_departemen, ms_golongan, ms_suku, ms_sim, ms_asuransi, ms_hubungan, ms_cutikaryawan, ms_hobby, ms_statuskaryawan, ms_statusrumah, ms_agama, ms_golongandarah, ms_jeniscuti, ms_jenisijin, tr_ absensi, tr_organisasi, tr_headerkeluarga, tr_cuti, tr_ijin, tr_detailkeluarga, tr_pendidikaninformal, tr_computerskill, tr_pendidikan. Berikut merupakan rancangan logical model database Sistem Informasi Human Resource PT Sinar Raflesia Selatan.

\section{Perancangan Interface Aplikasi Web}

Tahap ini merupakan perancangan interface aplikasi Sistem Informasi Human Resource PT Sinar Raflesia Selatan. Peneliti menggunakan software adobe photoshop untuk pembuatan rancangan interface Photoshop merupakan software yang digunakan untuk memodifikasi gambar atau foto.

Peneliti merancang interface absensi, login, home administrator, home karyawan, home kepala bagian, home direktur, ubah password, cuti, izin, rekap jam kerja, karyawan, form penambahan karyawan, departemen, form penambahan departemen, asuransi, form penambahan asuransi, golongan, form penambahan golongan, jabatan, form penambahan jabatan, suku form penambahan suku, agama, form penambahan agama, golongan darah, form penambahan golongan darah, jenis cuti, form penambahan jenis cuti, jenis izin, form penambahan jenis izin, status rumah, status karyawan, form penambahan status karyawan, hubungan keluarga, form penambahan hubungan keluarga, rekap jam kerja, mengajukan cuti karyawan, mengajukan izin karyawan, mengajukan cuti kepala bagian, rekap cuti kepala bagian, approve cuti kepala bagian, mengajukan izin kepala bagian, rekap izin kepala bagian, approve izin kepala bagian, rekap cuti direktur, approve cuti direktur, rekap izin direktur, approve izin direktur. Berikut merupakan perancangan interface absensi dan cuti.

\section{a. Rancangan Interface Absensi}

Pada rancangan interface absensi Sistem Informasi Human Resource PT Sinar Raflesia Selatan terdapat kolom foto user, kolom kode karyawan, tombol submit dan tombol login untuk masuk ke dalam akun user. Berikut merupakan tampilan halaman abensi. Seperti pada Gambar 13.

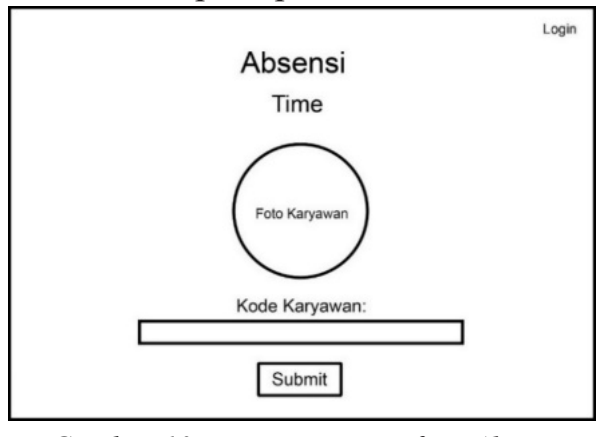

Gambar 13 Rancangan Interface Absensi

\section{b. Rancangan Interface Cuti}

Pada perancangan interface cuti terdapat beberapa tampilan diantaranya form pengajuan cuti, tampilan halaman cuti untuk admin, karyawan kepala bagian dan direktur.

1). Rancangan Interface Form Pengajuan Cuti

Berikut merupakan perancangan halaman form pengajuan cuti. Seperti pada Gambar 14.
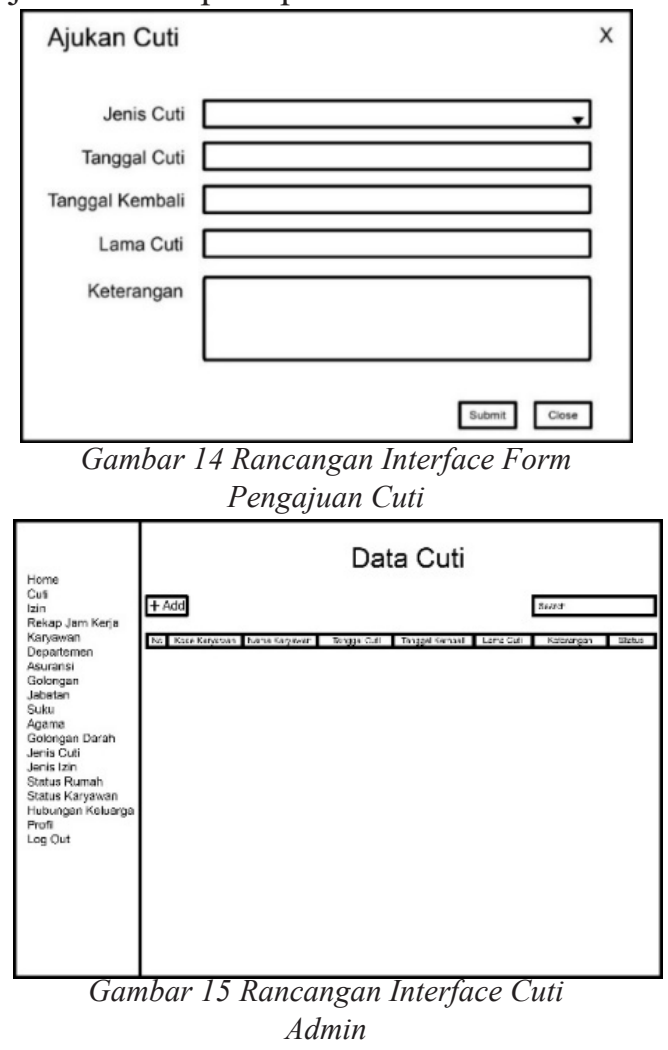


\section{2). Rancangan Interface Cuti Admin}

Berikut merupakan perancangan halaman cuti pada admin. Seperti pada Gambar 15.

3). Rancangan Interface Cuti Karyawan

Berikut merupakan perancangan halaman cuti pada karyawan. Seperti pada Gambar 16.

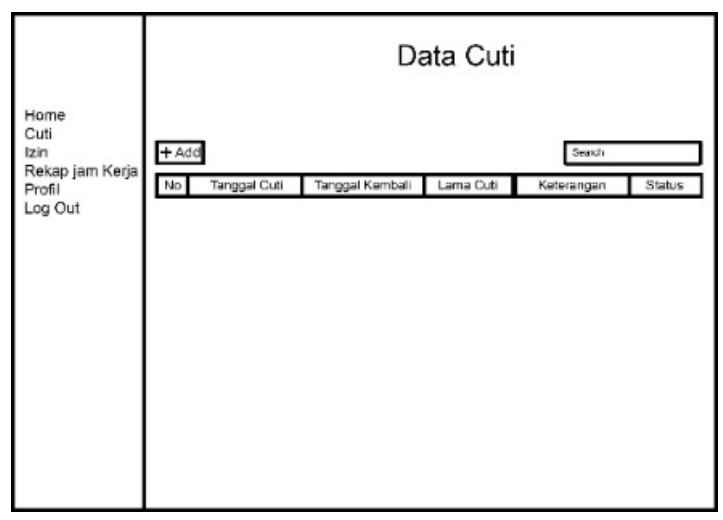

Gambar 16 Rancangan Interface Cuti

Karyawan

4). Rancangan Interface Cuti Kepala Bagian

Perancangan halaman cuti kepala bagian terdiri dari halaman pengajuan, halaman approve cuti dan rekap cuti. Berikut merupakan rancangan interface mengajukan cuti kepala bagian. lihat Gambar 17.

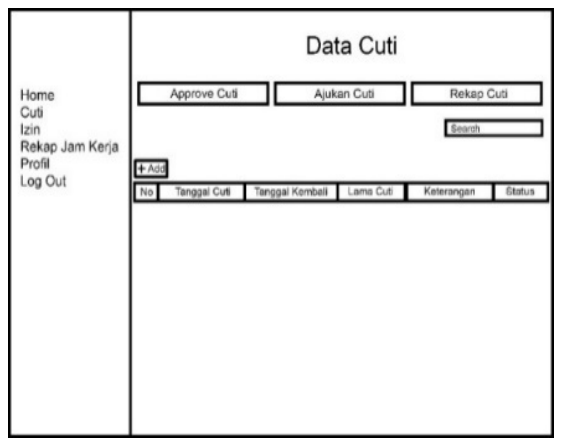

Gambar 17 Rancangan Interface Mengajukan Cuti Kepala Bagian

Berikut merupakan perancangan halaman approve cuti kepala bagian. Seperti pada Gambar 18.

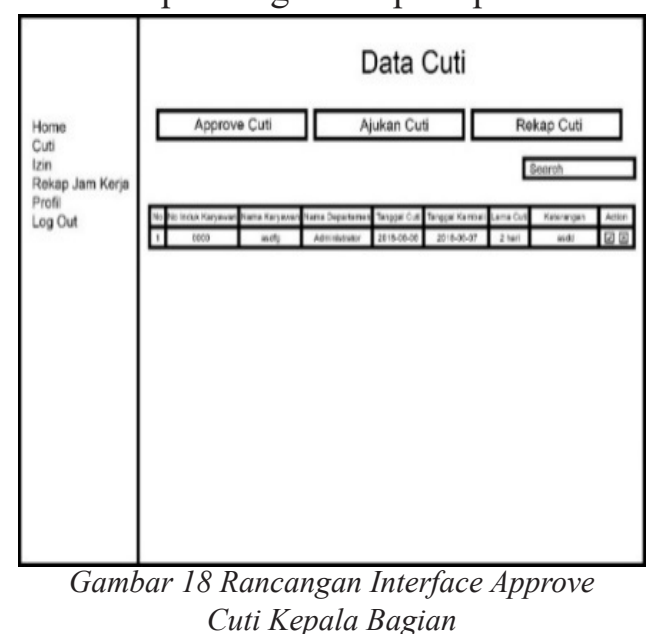

Berikut merupakan perancangan halaman rekap cuti kepala bagian. Seperti pada Gambar 19.

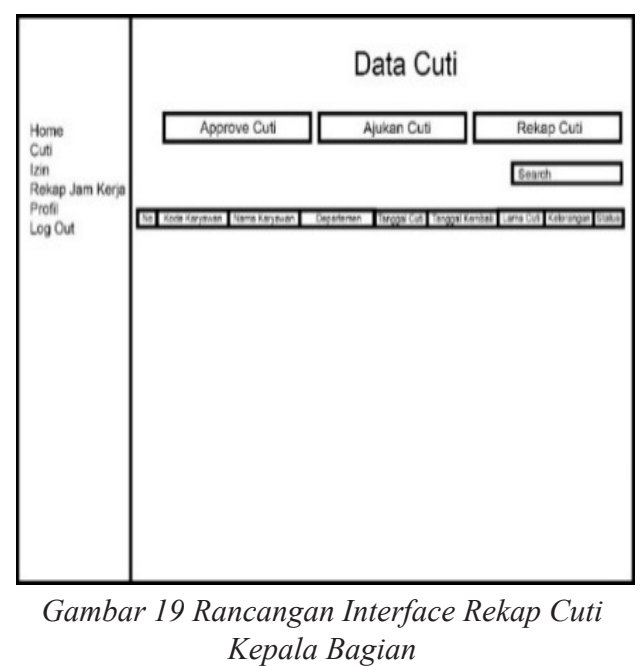

5). Rancangan Interface Direktur

Perancangan halaman cuti direktur terdiri dari halaman approve cuti dan rekap cuti. Berikut merupakan rancangan interface mengajukan cuti direktur. Berikut merupakan perancangan halaman approve cuti direktur. Seperti pada Gambar 20.

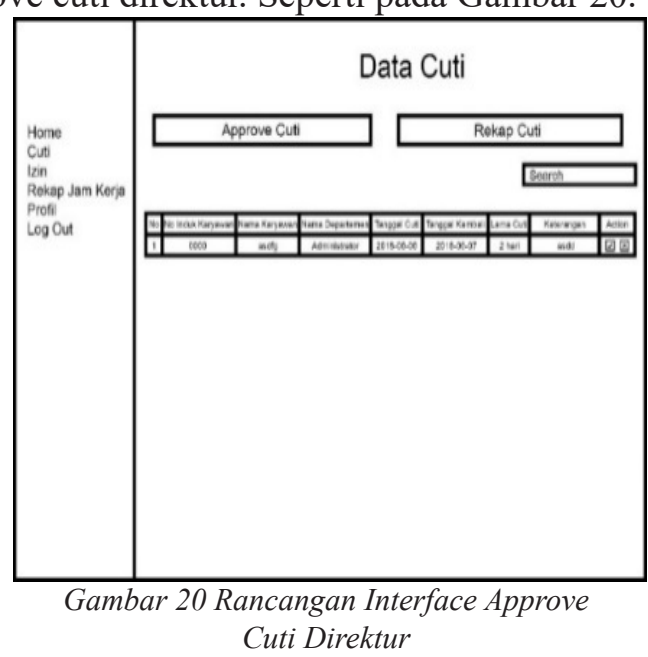

Berikut merupakan perancangan halaman rekap cuti direktur. Seperti pada Gambar 21.

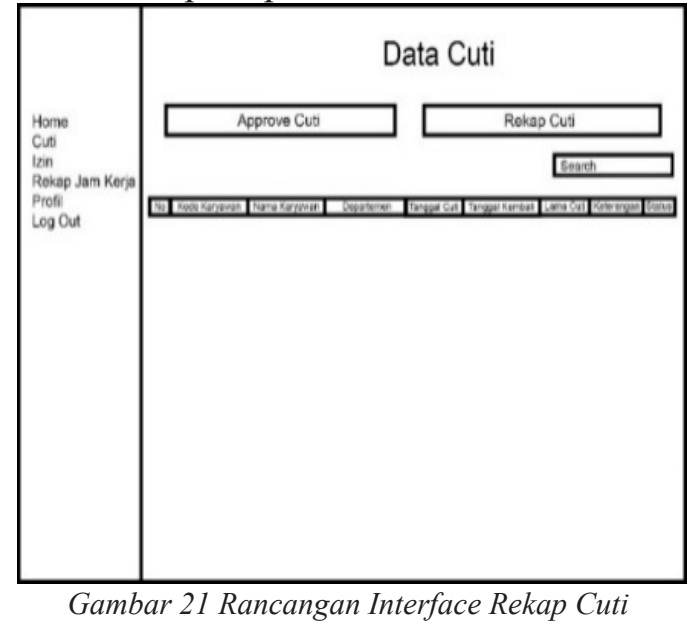

$$
\text { Direktur }
$$

\section{Implementasi}

Dalam tahap ini peneliti melakukan implementasi pemrograman sistem berdasarkan 
dari hasil perancangan sistem. Peneliti melakukan pengimplementasian pemrograman sistem menggunakan software sublime text 2 dengan bahasa pemrograman PHP. PHP merupakan merupakan sebuah bahasa scripting yang terpasang pada HTML, sebagian besar sintaks mirip dengan bahasa $\mathrm{C}$, Java dan Perl, ditambah beberapa fungsi PHP yang spesifik [11]. Sedangkan untuk pembuatan basis data peneliti menggunakan basis data MySQL. Peneliti melakukan pemrograman berdasarkan pada desain yang telah dirancang pada tahap sebelumnya dan akan menghasilkan script program dan tampilan aplikasi pada halaman web. Hasil dari sistem informasi human resource ini telah diuji, tetapi belum diterapkan pada PT Sinar raflesia Selatan.

Program yang telah selesai dilakukan oleh peneliti menghasilkan output program Sistem Informasi Human Resource Berbasis Web pada PT Sinar Raflesia Selatan. Tampilan halaman web terdiri dari halaman login, halaman absensi, halaman home administrator, halaman home kepala bagian, halaman home direktur, halaman ubah password, halaman cuti, halaman izin, halaman rekap jam kerja, halaman karyawan, halaman form penambahan karyawan, halaman karyawan departemen, halaman departemen, halaman form penambahan departemen, halaman asuransi, halaman form penambahan asuransi, halaman golongan, halaman form penambahan golongan, halaman jabatan, halaman form penambahan jabatan, halaman suku, halaman form penambahan suku, halaman agama, halaman form penambahan agama, halaman golongan darah, halaman form penambahan golongan darah, halaman jenis cuti, halaman form penambahan jenis cuti, halaman jenis izin, halaman form penambahan jenis izin, halaman status rumah, halaman status karyawan, halaman form penambahan status karyawan, halaman hubungan keluarga, halaman form penambahan hubungan keluarga, halaman rekap jam kerja, halaman mengajukan cuti karyawan, halaman mengajukan izin karyawan, halaman mengajukan halaman cuti kepala bagian, halaman rekap cuti kepala bagian, halaman approve cuti kepala bagian, halaman mengajukan izin kepala bagian, halaman rekap izin kepala bagian, halaman approve izin kepala bagian, halaman rekap cuti direktur, halaman approve cuti direktur, halaman rekap izin direktur, halaman approve izin direktur. Berikut merupakan perancangan interface absensi dan cuti.

\section{Interface Absensi}

Pada interface absensi berfungsi untuk user melakukan absensi hadir dan pulang. Interface ini menyediakan kolom kode karyawan dan tombol Submit untuk menyimpan jam masuk dan keluar karyawan ke dalam sistem yang sebelumnya sudah tervalidasi sesuai dengan kode user yang telah diberikan. Berikut merupakan inteface absensi. Seperti pada Gambar 22.

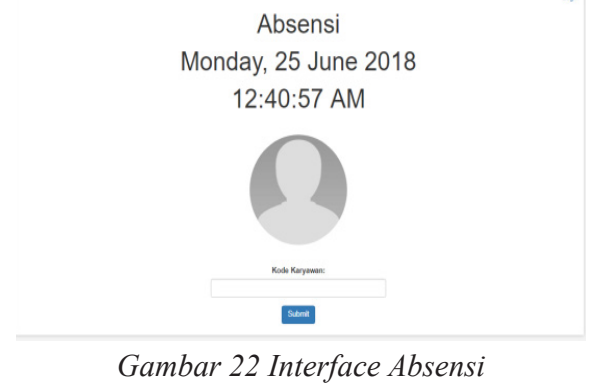

2. Interface Cuti

Pada interface cuti terdapat beberapa tampilan sesuai dengan user masing-masing yaitu admin, karyawan, kepala bagian dan direkur.

a. Interface Cuti Admin

Berikut merupakan tampilan halaman Interface cuti admin. Seperti pada Gambar 23.

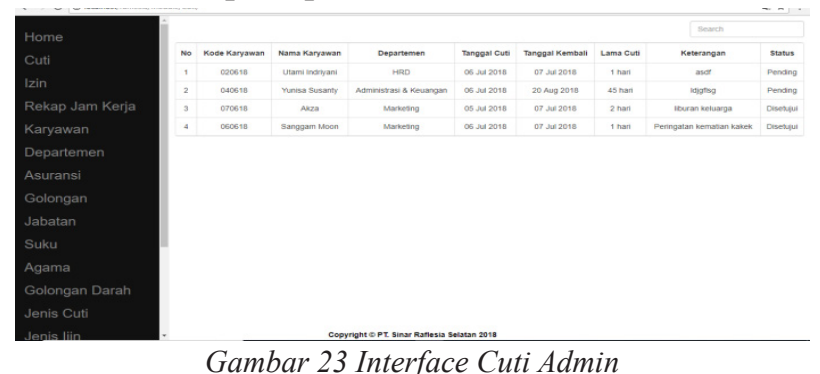

b. Interface Cuti Karyawan

Berikut merupakan tampilan halaman Interface karyawan. Seperti pada Gambar 24.

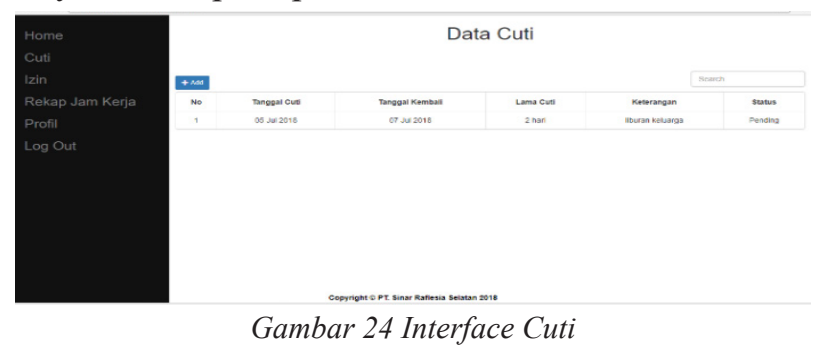

c. Interface Kepala Bagian

Interface cuti kepala bagian terdiri dari halaman pengajuan, halaman approve cuti dan rekap cuti. Berikut merupakan interface mengajukan cuti kepala bagian. Seperti pada Gambar 25, Berikut merupakan Interface approve cuti kepala bagian. Seperti pada Gambar 26, Berikut merupakan Interface rekap cuti kepala bagian. Seperti pada Gambar 27.

d. Interface Direktur

Interface cuti direktur terdiri dari halaman approve cuti dan rekap cuti. Berikut merupakan 


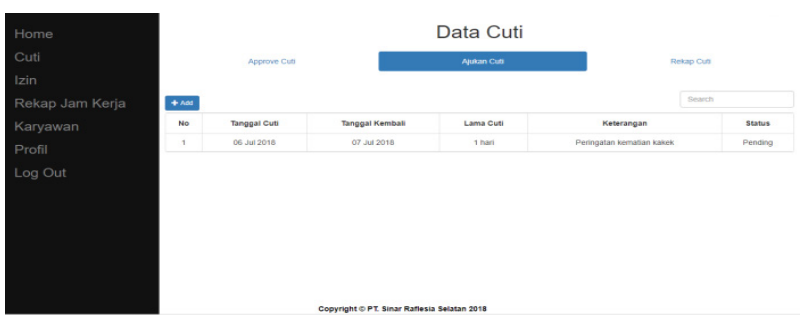

Gambar 25 Interface Mangajukan Cuti Kepala Bagian

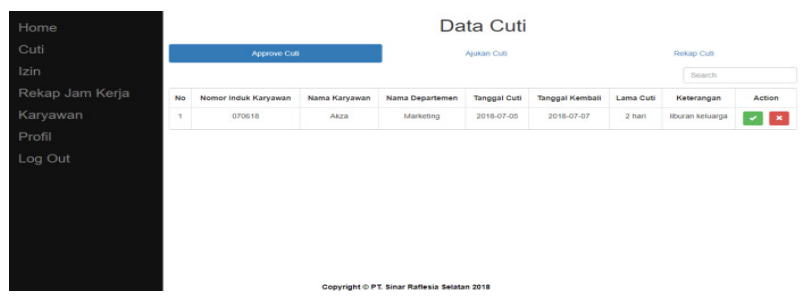

Gambar 26 Interface Approve Cuti Kepala Bagian
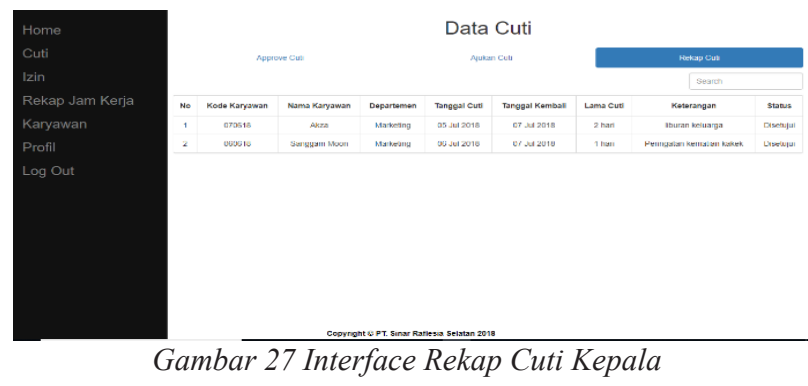

Bagian

interface approve cuti direktur. Dapat dilihat pada Gambar 29.

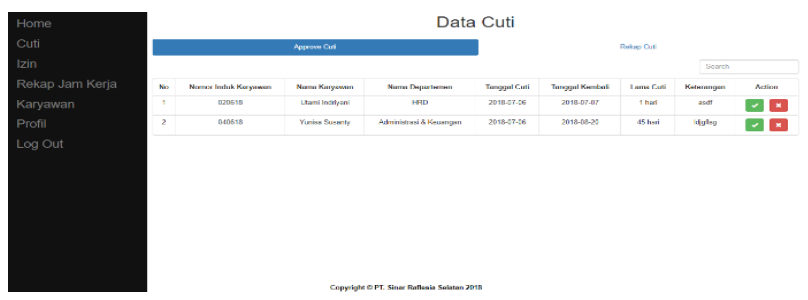

Gambar 29 Interface Approve Cuti Direktur

Berikut merupakan halaman Interface rekap cuti direktur. Seperti pada Gambar 30.

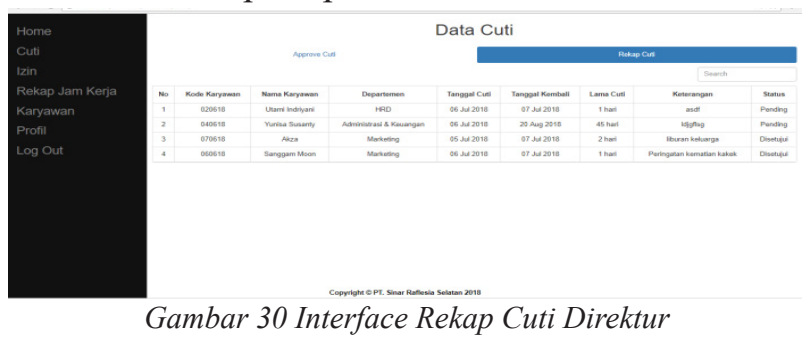

\section{Pengujian Sistem}

Pengujian yang dilakukan peneliti pada aplikasi sistem informasi human resource PT Sinar Raflesia Selatan berbasis web adalah menggunakan black box testing dengan klasifikasi alpha testing. Pengujian dilakukan langsung kepada end-user terhadap fungsi dari setiap menu yaitu login dari setiap user, data karyawan, absensi karyawan, cuti karyawan, izin karyawan, konfirmasi cuti karyawan, konfirmasi izin karyawan, status cuti karyawan, dan status izin karyawan. Pengujian ini dilakukan peneliti untuk mengevaluasi sistem yang telah dihasilkan yaitu sistem sesuai dengan harapan dan kebutuhan fungsional yang ingin dicapai. Dengan pengujian tersebut diharapkan akan mendapatkan hasil sesuai dengan kebutuhan sistem.

\section{SIMPULAN}

Sistem yang dibangun oleh peneliti adalah Sistem Informasi Human Resource PT Sinar Raflesia Selatan berbasis web. Sistem ini menyajikan informasi data karyawan, absensi, cuti dan izin untuk karyawan, kepala bagian, direktur dan HRD. Metode pengembangan waterfall sesuai dalam pembangunan sistem informasi human resource karena peneliti diharuskan untuk melakukan analisis permasalahan secara mendetail dengan pengumpulan data melalui wawancara dan observasi. Pemodelan system dengan menggunakan UML dapat menggambarkan secara jelas system yang akan dibangun pada user. Pengujian sistem dilakukan dengan menggunakan black box testing klasifikasi alpha testing berdasarkan kebutuhan fungsional sistem yang sesuai dengan pengembangan sistem serta evaluasi sistem karena dilakukan kepada user.

\section{DAFTAR RUJUKAN}

[1] Taufiqurokhman, dalam Mengenal Manajemen Sumber Daya Manusia, vol. 10, Jakarta, Andi, 2009, p. 1.

[2] A. F. Wulandari dan Y. Yamasari, "Sistem Informasi Manajemen Sumber Daya Manusia (Studi KAsus Bumi Syariah)," Jurnal Program d3 Manajemen Informatika, Universitas Negeri Surabaya, Surabaya, vol. 1, pp. 1-2, 2012.

[3] O. Tariq, J. Sang dan K. Gulzar, "International Journal of u- and e- Service, Science and Technology," ResearchGate, vol. 9, pp. 15-24, 2016.

[4] J. Rusjiana, "Pengaruh Sistem Informasi SDM Terhadap Kinerja Karyawan di PT. Rabbani Bandung," Jurnal Computech \& Bisnis, vol. 10, p. 24, 2016.

[5] Jogiyanto, dalam Ssistem Teknologi Informasi Edisi III, Yogyakarta, Andi, 2008, p. 54.

[6] A. Kadir, dalam Pengenalan Sistem Informasi Edisi Revisi, vol. 1, Yogyakarta, Andi, 2014, p. 218.

[7] A. d. Saeger, dalam Ishikawa Diagram Anticipate and Solve Problems within Your Business, Lemaitre Publishing, 2015, p. 6.

[8] R. A. Sukamto dan M. Shalahuddin, dalam Rekayasa 
Perangkat Lunak Terstruktur dan Berorientasi Objek, vol. 4, Bandung, Informatika, 2013, pp. 141-163.

[9] A. Nugroho, "Unified Modeling Language (UML)," JURNAL KHATULISTIWA INFORMATIKA, vol. 4, pp. 1-15, 2016.

[10] R. A. Sukamto dan M. Shalahuddin, dalam Rekayasa Perangkat Lunak Terstruktur Berorientasi Objek, vol. 1, Bandung, Informatika, 2012, pp. 50-51.
[11] A. F. Wulandari dan Y. Yamasari, "Sistem Informasi Manajemen Sumber Daya Manusia (Studi Kasus Bumi Syariah), Jurnal Program D3 Manajemen Informatika, Universitas Negeri Surabaya, Surabaya, vol. 1, p. 2, Oktober 2012. 